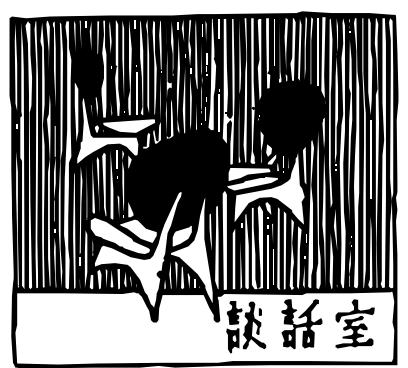

\title{
AsCA2018 会議参加記
}

\section{AsCA2018に参加して}

\section{早稲田大学先進理工学研究科 寺澤有果菜}

2018 年 12 月 1 日から 12 月 5 日に開催された, 第 15 回 アジア結晶学連合会議（AsCA 2018）に参加してきまし た. 本学会では, ワークッショップへの参加, 研究発表 の聴講, 自身の研究発表を行いました. AsCAに参加し たのは今回が初めてで,アジアに扔ける結晶学の研究の 現状を知ることができました。

\section{ニュージーランド・オークランドについて}

学会は, ニュージーランドのオークランドで開催され ました。ニュージーランドは南半球にある島国で, 面積 は日本の約 $70 \%$ です. 日本との時差は 4 時間で, 日本か らの直行便で約 10 時間でした。 ニュージーランドは, 北 島と南島に分かれており，オークランドは北島の北部に 位置する港町です，天候は変わりやすく，一日の中で四 季があると言われるほどです，実際，昼間は暖かく，夜 は寒いというような天気で, 数時間の中で晴れと雨を繰 り返すような不安定な天気でもありましたが，全体的に 過ごしやすかったです

オークランド空港に着いて，マオリ族のゲートをくぐ りました．現地に到着してすぐにニュージーランドっぽ さを感じられました。空港から学会会場までは離れてい て,バスで片道約 40分でした。学会会場付近は観光地 で，多くの観光客がいました，オークランドのシンボルで あるスカイタワーは, 学会会場から徒歩で約 20 分のとこ ろにありました，東京タワーやスカイツリーよりはずっ と低かったですが，オークランドの街を一望することが できました，さらに，スカイタワーから徒歩で約 20 分北 上すると, 港が見えてきます。バイアダクトハーバーと 呼ばれる港があり，海なし県で生まれ育った私にとって は，海を近くに感じられたことがとてもうれしかったで す。また，橋が建設されており，バイアダクトハーバー を一周できるようになっていました。明るい港ももち ろん良かったですが，それにも増して夜景が綺麗でした (写真1). 港付近には，レストランが立ち並んでおり，ラ ム肉やオイスター,グリーンマッスルなど, ニュージー ランドの食事を楽しむことができました，また，ニュー ジーランドで有名なホーキーポーキーというアイスク リームも食べました（写真1)。ニュージーランドの街を
歩き, 現地の人たちとの交流を通じて, ニュージーラン ドの生活や文化を知ることができ，非常に良い社会勉強 ができました。

\section{ワークショップについて}

ワークショップは, 学会開会の前日12月1日に開催され ました. Olex2-CCDC, CCP4-Autorickshaw, LCP-Lipidic phase workshop, Combined workshop : 1) SBGridStructural biology software infrastructure, 2) Synergistic use of diffraction and spectroscopic use of diffraction and spectroscopic methods at XFEL and synchrotron sourcesの 4つのワークショップがパラレルで行われました。

私は, Olex2-CCDCに参加しました。結晶構造解析ソ フトウェアOlex2を提供しているOlexSys, CSDを提供 しているCCDCの社員の方々による講義および実演でし た(写真2). Olex2のワークショップでは, ソフトウェア の概要, 使い方を学びました，その後，モニターに映し ながら, Olex2を使って実際にいくつかの構造解析を実 演してくださいました。コマンドに代わってグラフィッ ク上でできる操作が多く, 特に複雑な構造解析では使い

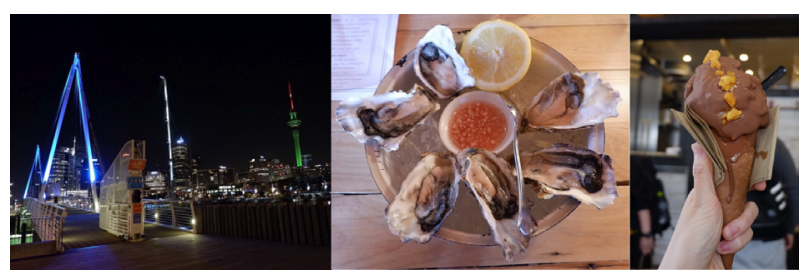

写真 1 バイアダクトハーバーの夜景, 食事

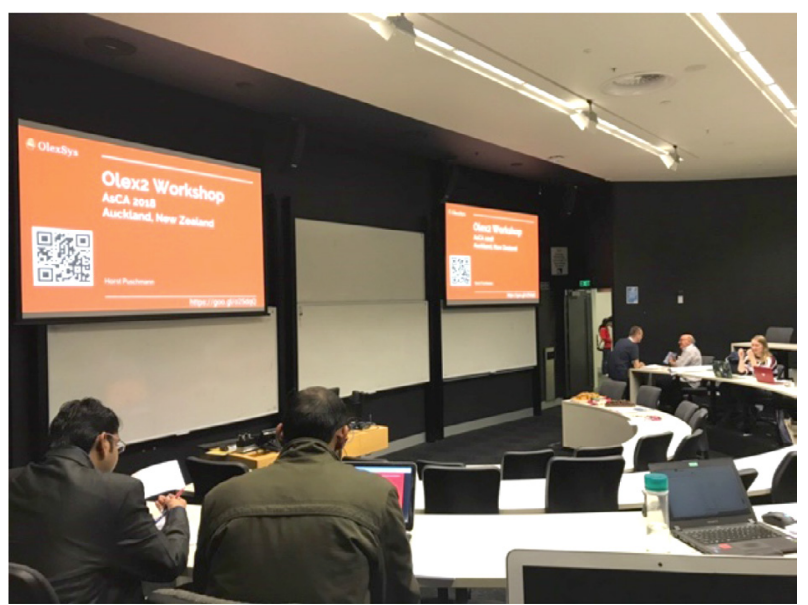

写真2 Olex2ワークショップの様子

日本結晶学会誌 第61巻 第1号 (2019) 
やすいと感じました，日本でのOlex2 は海外と比べて浸 透していないのですが, フリーソフトなので今後広まっ ていくといいなと思いました. CSD のワークショップで は, $\mathrm{CSD} の$ 使い方および登録の仕方の説明, $\mathrm{CCDC}$ が提 供しているソフトウェアの紹介などがありました，また， 仕事の 1 つして, 近年のデータベースから, 登録件数 の推移や登録される結晶の種類などの傾向を割り出し ていることも知り, 結晶学の研究の潮流を知る 1 つの指 標になると感じました。

\section{学会について}

学会会場は, ワークショップと同じオークランド大学の Owen G. Glenn Buildingでした. Owen G. Glenn Building は, 工学部のキャンパスにあり,オフィスビルのような 外観でした (写真 3). 口頭発表 107 件, ポスター発表263 件, これに加えキーノートや基調講演などがありました。 口頭発表は 18 , ポスター発表は4のテーマに分かれて, 2日間で行われました，材料分野や生体関連分野，また 低分子からタンパクまで多種多様な研究があり, 非常に 面白かったです、私は材料寄りの研究なので，あまり身 近でない夕ンパクの研究をたくさん聞くことができたこ とは, とても良い刺激になりました。

私自身はポスター発表を行いました。発表を聞きに来 てくださった方々は，1つ1つ熱心に聞き入って，たくさ んデイスカッションしてくださいました，自分や身近に いる方々とは異なる視点から質問をしてくださったり， 実験手法についてのアドバイスもしてくださいました。

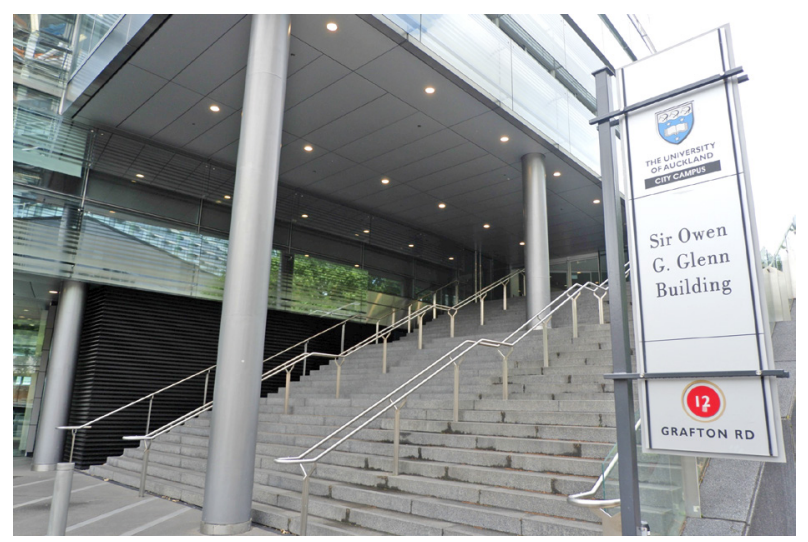

写真3 学会会場の建物

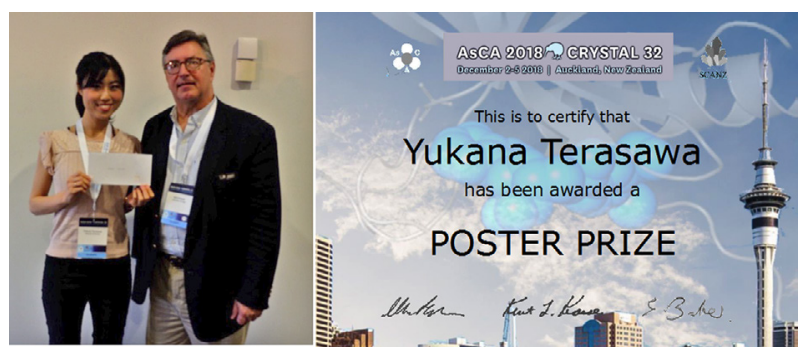

写真4 オーガナイザーの Kurt Krause 先生と Poster Prize の記念写真, 賞状
新たな知識を得ることができ, かつ参加者同士でネット ワークを形成することもでき，とても有意義な時間だっ たと感じています，また，本発表で Poster Prizeを受賞で きたことをとても嬉しく思います（写真4).

今回, さまざまな発表を聞いて刺激を受けたように, 私も自分自身の研究に興味をもってもらえるような魅力 的な発表をできるようになりたいと思いました，そのた めには, 広い視野をもち, 分野を超えた研究を知る必要 があると感じました，今後も積極的に研究活動を行い, 知見を広げていきたいと思います。

最後に, 本学会参加にあたり,リガクファンドによる 日本結晶学会 2018 年度国際会議参加助成のご支援を賜 りました. 日本結晶学会および株式会社リガク様に深く 感謝申し上げます。ありがとうございました。

\section{AsCA2018参加報告}

筑波大学数理物質科学研究科 出口裕佳

12月2日から5日にかけて, ニュージーランドの オークランド大学Owen G Glenn Building で開催され たAsCA2018/CRYSTAL 32 (A combined conference of the Asian Crystallographic Association (AsCA) and the Society of Crystallographers in Australia and New Zealand (SCANZ)）に参加いたしました。オークランド大学は オークランド州の中心街に位置しており, 都会の印象を 受けました. 写真5にフェリー乗船中に撮影したオーク ランド中心街の写真を示します. 中央に見えるタワーは 南半球で最も高い建物, 高さ $328 \mathrm{~m}$ の Sky towerです.こ のほか高層ビルがいくつも並んでいました，街中を歩い ていると中国人, 日本人をはじめとするアジア人に出会 うことが多く，時に外国に来たことを忘れるほどでした。 滞在期間中は初夏であり, 最高気温は約 $20^{\circ} \mathrm{C}$ と日本よ りやや高い程度でした. 12 月に入道雲や紫陽花を見るの はとても新鮮でした. 日の入りは $20: 30$ 頃と遅く, 昼間 の時間がこの時期の日本より 5 時間ほど長いため, 得を した気分になり, 毎晚遅くまで出歩いてはレストランで

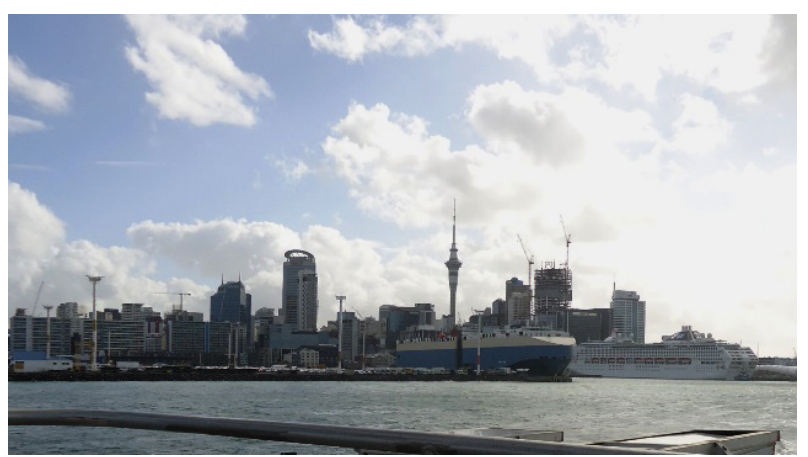

写真5 フェリーから見たオークランド中心街 
の食事や街中の観光を楽しみました.

AsCA2018は自身にとって, インドのハイデラバード で開催されたIUCr2017, カナダのハリファックスで開 催されたSagamore2018に続く3回目の国際会議参加で した。直行便を利用しての渡航は初めてで, 移動が楽で あろうと予想し, 事前の発表練習もほどほどに飛行機に 搭乗しました，予想は外れ，大きく摇れかつ深夜便でラ イトの付いていない機内ではほとんど練習ができず, 結 果として滞在期間中に毎晚深夜 2 時過ぎまで練習するこ ととなりました，期待せず事前によく練習をしておくべ きだったと反省いたしました。

AsCA and SCANZ プログラムは4つのPlenary, 6つの Keynote, 18 の Micro symposium, 2つの Workshop, ほか に General interest symposium と Rising star symposium か ら構成されていました. Micro symposiumは最大 3 会場で の平行開催でした. ポスターセッションは初日と2日目 の夜に2力所で開催されました。講演, ポスターを含め て生物分野の発表が最も多い印象でした，次いでMetal organic frameworks (MOF) に関する発表が多く, それら の発表では質疑応答も活発でした. 自身の研究分野であ る電子密度研究の発表は非常に少なく残念でした。これ まで参加した国際会議と比較して座長, スタッフ, 参加 者を含めて女性が多いと感じました。

初日のOpening ceremonyに続いて行われたGeneral interest symposiumにおいて, ライス大学George Phillips教授は The future of crystallography -or not というタイトルで講演 を行われました. 今後発展していく分野として 2 色ポン ププローブ法を使用した時分割測定, small molecule, 時 分割タンパク質結晶学, X線自由電子レーザー (XFEL) といったキーワードが並びました。

3 日目の Keynoteのスウェーデンのグーテンベルグ 大学Richard Neutze教授による Time-resolved diffraction experiments at X-ray free electron lasers reveal ultrafast structural changes in photosynthesisは, 会場が一杯になる ほど注目を集めていました。照射損傷の前に回折デー 夕を取得するという手法の概念の説明から, 2011 年に Chapmanらにより報告されたLCLS での光合成タンパク の時分割回折実験と, ピコ秒の時間スケールでの構造変 化について丁寧に説明されていました. 現在進行中の SACLAでの実験についての紹介もあり, 非常に貴重な 経験でした。

最終日の4日目には, SCANZ Bragg Lectureが行われ ました.シドニー大学の Mitcell Guss教授は, My life in crystallographyと題して幼少期, 学生時代, そして 54 年 間の研究生活を振り返り, キャリアを確立する上で印 象的だったでき事などを説明されました.1953年の Structure biologyの会議の写真には, 私も知っているノー ベル賞受賞者がたくさん写っており, 胸が躍りました.
1960 年代の研究例としては手描きの電子密度分布, 最 小二乗法で誤った重みを使用することについての論文が 紹介されました.今日の結晶学は多くの偉大な研究者の 試行錯誤の積み重ねにより成り, 巨人の肩の上に立つと はまさにこのことだと感じました。

ダイヤモンドの電子密度に関する研究成果を, 最終 日の午後に開催されたRising star symposiumにて発表い たしました，今回Rising Star Awardを受賞したのは6名 で, 3 名がタンパク質, 3 名が化学, 物理分野でした. 発 表で割り当てられた時間は質疑応答を含み 20 分でした。 写真 6 は発表中の写真です. 会場は 400 名程度収容可能 なホールで, 手前の大きなスクリーンにスライドが2枚 表示されていました. 最初に発表されたインドのInstitute of Stem Cell Biology and Regenerative Medicineのポスド ク研究員 Dr. Sanchari Banerjeeは, ゴキブリ中でin vivo で成長させた天然の不均一タンパク質の結晶構造を, XFELを利用して決定し報告されました。成果はすでに 各地で報道されており, 大変インパクトが大きく, 質問 応答も活発でした。オーストラリアのシドニー大学の Ms. Katrina ZenereはSCANZ Mathieson medal を受賞し たDr. Suzanne Naville, Plenaryを行ったCameron Kepert 教授の研究グループのポスドク研究員で, MOFのSpin crossoverについて発表していました。 ほかの受賞者も数 年前から研究成果を出しており, 修士 2 年の私からみれ ば十分ベテランでした，私以外の発表者は発表前にはリ ラックスして, 特に準備をすることなく落ち着いていま した. 緊張して原稿にかじりついている自身にも気さく に「おめでとう!」と声をかけてくださり, 器の大きさ の違いを感じました。素晴らしい受賞者とともに一緒に 発表できることを嬉しく感じました.

AsCA2018は私にとって学生生活最後の国際会議であ り，集大成を発表する場となりました，会議に参加して

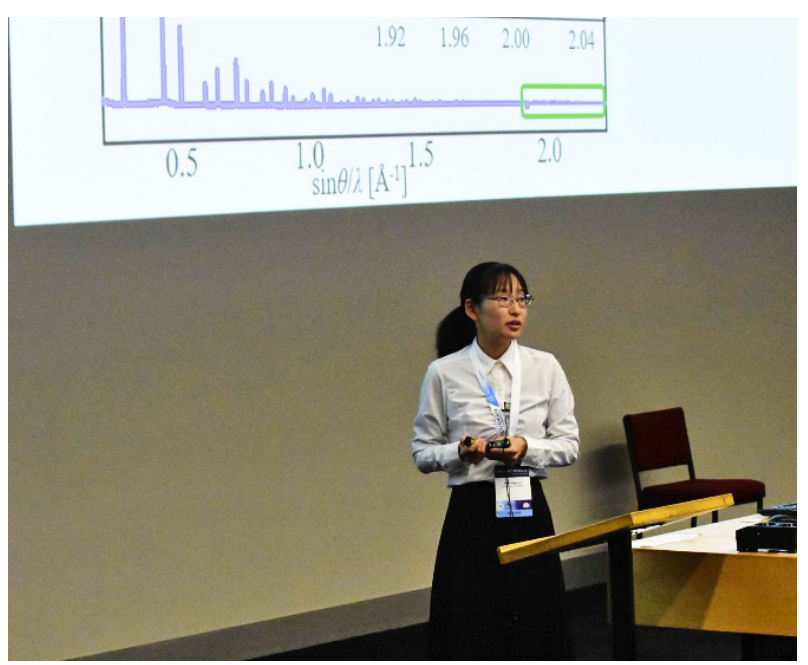

写真6 発表中の写真AsCA2018の Facebookページより 入手 
最新の成果に触れ, 充実したデイスカッションができ, 同年代の国内外の学生の方と親しくなることもできま した。この場を措りしてご支援くださいましたりガク ファンド, 日本結晶学会2018年度国際会議参加助成の 関係者の皆様に心より感謝を申し上げます。

\section{AsCA2018 Auckland参加報告書}

東京大学大学院薬学系研究科 清水 光 ニュージーランドの北島に位置するオークランド のオークランド大学で 12 月 $2 \sim 5$ 日にかけて第 32 回 AsCA2018が開催された. 現地の気温は $20^{\circ} \mathrm{C}$ 前後と過ご しやすい一方で, 天候は変わりやすく頻繁に俄雨が降っ ていた．私にとっては初のオセアニアへの渡航であり， 勝手がわからず多くの服をスーツケースに詰め込んで しまったが, 結果的にはシャツと薄手のコートで十分と いった具合であった。オークランドの街は活気に溢れ, 新鮮な魚介類や肉, 乳製品を食べることのできる実にグ ルメな街であった。

オープニングセレモニーに先立って4つのワーク ショップが開催された. 私はLipidic cubic phase (LCP) workshopに参加した. 参加者は演者も含めて 30 人程度 と比較的小規模でお菓子もふるまわれながらアットホー ムな䨌囲気で行われた. 7 人の演者による LCP 法の概略 やケーススタディおよびLCP法により得られた結晶を シンクロトロンやXFELでどのように扱いX線を当てる か, そのための試料調製方法などの説明がなされた。 ま た午後の部では実際にLCP作製と結晶化ロボットによ る結晶化の体験をした，参加者のほとんどはLCP法初心 者であり, 私もその一人だったが親切丁寧な実演をして いただき, 紙面に書かれるプロトコルでは表現できない 手技の注意点やコツを教えていただいた.

オープニングセレモニーでは各国からの参加者数が発 表され, 日本からはニュージーランド, オーストラリア といったオセアニア諸国に次いで約 90 名が参加してい るようであった．アジア各国からの参加者と比較的少数 であるが欧米からの参加者もおり国際性豊かな会である と感じた。

会期中はパラレルに3つのMSセッションが開催され た. 構造生物学の分野では膜タンパク質の構造解析や近 年目覚ましい進歩を遂げた cryo-EMやXFELについてな ど多くのセッションが開かれ，どのMSに出席するかお おいに迷った。

私が注目した発表は米国UCLAのTamir Gonen氏に よる microEDについての講演であった（Gonen氏はオー クランド大学出身). プレゼンは単粒子解析の成果に よって世界に名を轟かせる Titan Krios（Thermo Fisher Scientific社) のフロント面には回折点を模したロゴが印 刷されており, この装置は本来結晶構造解析のための装 日本結晶学会誌 第 61 巻 第 1 号 (2019)
置である，という軽快なジョークから始まった。通常の X線回折実験では考えられないナノメートルオーダーの 微小結晶から構造解析を実現する microEDの強力な手 法を解説し, 現在どこまで取り組みが進んでいるのかに ついて説明した。電子線散乱の永遠の課題である薄い結 晶の作製について, 彼らの実験グループでは大きな結晶 を破砕するという実に大胆かつシンプルな方法をとって いた，また，最近ではレーザーによって結晶を削り薄膜 状にしたうえで回折像を取得するといったよりソリッド な方法もあるようだ. microEDに使用可能なナノ結晶は 一見 granular milky solutionに見えるような結晶化溶液内 にも析出している場合があるということなので驚きで あった。これまで本手法で構造解析された分子の例では ペプチドなどの比較的小さな構造体が多い印象であっ たが, 膜タンパク質でも 1例 (PDBID：6CPV) 構造解析 がなされており, 広範囲に適用可能なように思われた。 Gonen 氏の講演に対する注目度は高く, 活発な質疑が行 われた. 各国の構造生物学者らから LCP法により得た結 晶についても適用可能か, 新規構造の位相決定をどのよ うにするかなどクリティカルな質問がなされた. Gonen 氏はどの質問にも前向きな返答をしており，これから本

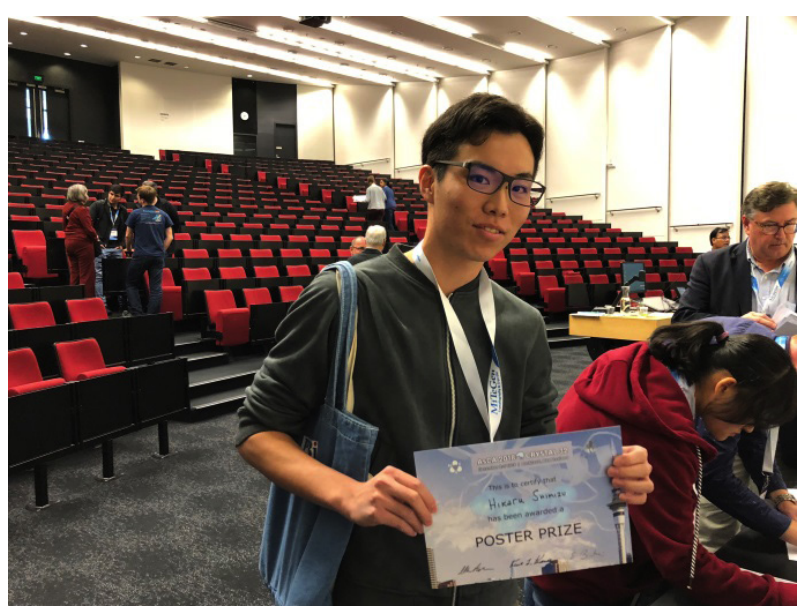

ポスター賞ゲット!

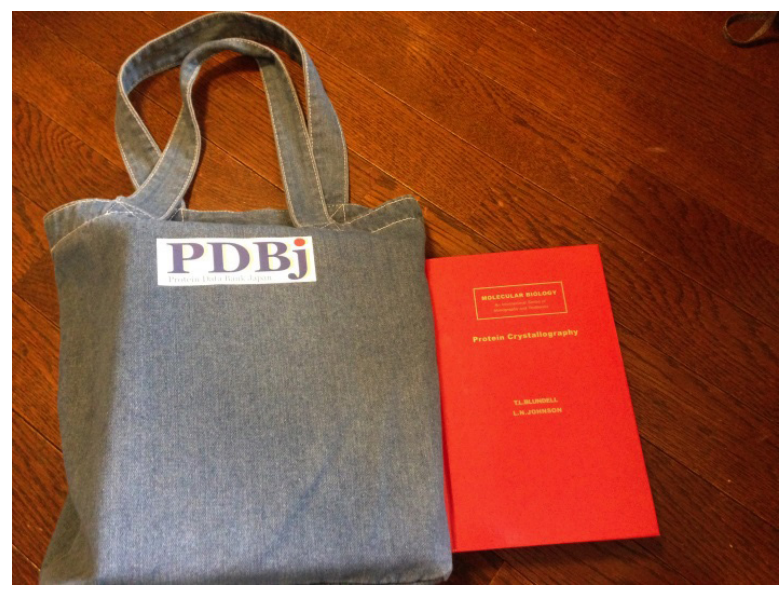

副賞の本とPDBj特製トートバッグ 
手法が普及していくことを予感させた。

ポスター発表では 250 以上のポスターが2日に分けて 張り出された。私は2日目 $(12 / 3)$ に発表を行った。慣 れない英語に苦戦しながらもなんとか 10 名程度のお客 さんに説明できた，海外での学会に参加するのは今回 が2回目だが，前に比べて多くの方が聞きにきてくれた のでそれだけでうれしかった。また，光栄なことにポス ター賞 $(\mathrm{PDBj}$ 賞) をとることができた. PDBj賞は今年 から新設された賞のようで副賞としてBLUNDELLと JOHNSONが43年前に執筆した “Protein crystallography” （なんとBLUNDELL本人のサイン入りのもの! ) をいた だた。このような歴史的にも価值のある著書をいただ き責任を感じるとともに, これを今後のモチベーション として構造生物学のさらなる発展に貢献できたらいいな と思った。

最後に今回の AsCAの参加にあたっては, 日本結晶学 会より参加助成をいただきました。このような貴重な機 会を提供くださりましてありがとうございました。 ご支 援いただきました日本結晶学会ならびに関係者の皆様方 に厚くお礼申し上げます。

\section{AsCA2018参加報告}

筑波大学数理物質科学研究科 藤田知樹

\section{はじめに}

2018 年 12 月 2 日から 5 日にかけてニュージーランドの オークランド大学で開催されたAsCA2018/CRYSTAL 32 の合同会議に参加した.オークランドは, 高さ $328 \mathrm{~m}$ の スカイタワーを中心部にもつニュージーランド最大の 都市である. 折しも現地は初夏であり, 道端に咲いた紫 陽花が印象的であった. 到着初日は毎年恒例のサンタパ

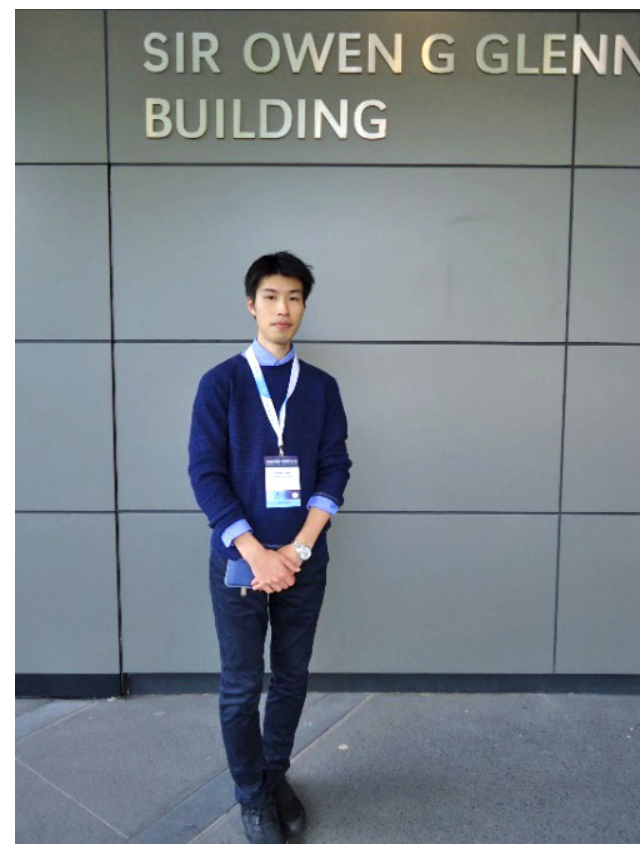

会場前にて
レードの開催日であり，街中にはアジア系を中心に観光 客が多く見られた. 時々日本語も聞こえるため, 外国に 来たという実感がなかなか湧かなかった. 会議の会場は, オークランド大学の Sir Owen G. Glenn Buildingであっ た. 初日のシンポジウム, 初日と 2 日目のポスターセッ ション, 2 日目から最終日まで行われたオーラルセッ ションに参加した. 最終日のオーラルセッションで, 研 究発表を行った。余談であるが, 初日は気温が $20{ }^{\circ} \mathrm{C}$ と暖 かく, 半袖で会場入りしたところ, あまりの冷房のきつ さに最初のシンポジウムで唇が紫色になり, 宿舎に上着 を取りに戻る羽目になってしまった。

\section{会議の感想と印象に残った講演}

AsCA2018/CRYSTAL 32 では, セッション全体を通し て, 新しい結晶学の手法に対して惜しみなく時間が割り 当てられていた。 クライオ電子顕微鏡をテーマとした オーラルセッションだけで2つ存在し, 分野に対する注 目度の高さと発展の著しさを感じることができた．X線 自由電子レーザーの分野では, SACLA, LCLSおよび EuroXFELにおける最新の結果が報告された。特にシリ アルフェムト秒X線結晶学 (SFX) について, 粉末試料 を用いた新しい構造解析技術の進展が報告されていた。 嬉しかったことは, 私の研究分野であるその場観察の研 究がいくつも報告されていたことである.オーラル・ポ スターセッションともに，4日間を通じて退屈するとい うことはいっさいなかった。

会議を通じて最も印象的だった講演は，3日目に行わ れたJ. Park博士による液相透過型電子顕微鏡 (Liquid phase TEM）を用いたナノ粒子のその場観察研究である. グラフェンのシート間に挟んだ溶液中の微細粒子に電 子線を当て, 数 $\mathrm{nm}$ のナノ粒子 1 個について三次元の原 子配列の再構成に成功していた. 結果の鮮やかさはもち ろん, 高真空が必要な TEMで液体を利用する技術や測 定のアイディアに感銘を受けた. Park博士の英語のプレ ゼンが巧みであったことも印象的であった。

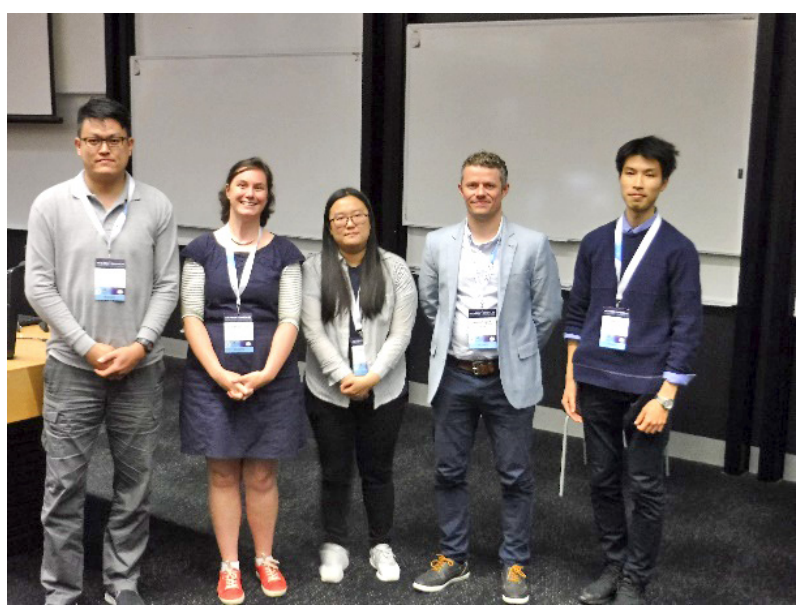

発表後の写真撮影

日本結晶学会誌 第 61 巻 第 1 号 (2019) 


\section{オーラルセッションにおける発表}

最終日の $10 ： 45 〜 12: 45$ に行われたオーラルセッショ ンMS\#18「Novel applications of Crystallography」におい て，20分間の発表の機会をいただいた，放射光を用いた ナノ粒子合成のその場観察研究の進渉を報告した，最終 日のためか, 想定していたよりも聴衆の人数は少なかっ た．外国人の聴衆を前にして英語でプレゼンを行う初 めての機会であり, 非常に緊張した。一方で当日になっ て発表者が 1 人欠席したため, 時間を長めに使ってゆっ くりと発表することができた. 発表終了後, 別のオーラ ルセッションでその場観察研究の発表を行っていたM. Rowles博士から結果の評価方法についてコメントをい ただいた，専門家と議論ができる貴重な機会であったの だが，内容をよく理解できず，有意義な意見交換にでき なかったことが悔やまれた，当たり前のことであるが， 自分の研究内容をよく理解して, たとえ英語であっても 適切に発信できるようにしておくことの重要さを身に染 みて実感することができた。

\section{おわりに}

AsCA2018では最先端の研究に触れて見聞を広めるだ けでなく, オーラルセッションでの発表という貴重な経 験を積むことができた. 研究内容から発表の仕方まで, 内容や気づきを片端から手元のノートに書き込み, 学び の多い4日間を過ごすことができて幸せであった. IUCr Young Scientists Awards 受賞し, 自分の研究を評価し ていただいたことも今後に向けての励みとなった，今回 はCoffee Breakや食事の時間の多くは日本人の参加者と 過ごしてしまったが, 周囲の参加者が学生・先生問わず 積極的に交流し，国を超えてお互いに対する理解を深め ていたことを思い出すと，もったいなかったと思う．次 に国際会議に参加する機会があれば, 新しい機会やつな がりを積極的に作りたい. 最後になりましたが, 本会議 は日本結晶学会国際会議参加助成プログラムのご支援の 下で参加させていただきました，プログラムのご支援先 である(株りガクならびに日本結晶学会の皆様に, この場 を借りて厚く㧍礼申し上げます。

\section{AsCA2018参加報告}

\section{はじめに}

\section{（国研）物質・材料研究機構 シンクロトロンX線グループ 廣井＼cjkstart慧}

筆者は日本結晶学会2018年度国際学会参加助成を受 ける機会をいただき，2018年12月2日〜 5 日に開催され たアジア結晶学会 (AsCA2018) に参加致しました. 当初 は口頭講演を希望しましたが叶わず，ポスターセッショ ンでの研究発表となりましたが, 講演を聞きに来てくだ さった方々と細部まで議論でき，確かな手応えを感じる ことができました。
筆者は長らく,アモルファス材料や液体試料などの構 造不規則系の原子構造㧍よび物性基礎を専門として研 究活動を行ってきました，そうした背景もあり，紹介し た研究手法が結晶学の研究者に受け入れられるのか不 安でしたが, その構造不規則系の解析手法は珍しく映っ たようで, 大勢の方々の興味を惹くことができました. また, ほかの研究者の発表を効率良く聞くことができ, 近年の結晶学研究のトレンドや方向性を理解する良い 機会となりました。

\section{AsCA2018}

AsCA2018は, ニュージーランド北島の都市オークラ ンド市街地にあるオークランド工科大学にて開催されま した. 口頭講演 (keynote, plenary talk含む) は 124 件, ポ スター講演は244件 (双方ともプログラムを参照) であ り, 大変盛り上がっていたような印象を受けました。一 般の口頭講演は3会場の parallel 形式で行われましたが, いずれも分野の重複が最小限となるよう配慮されてお り, どのセッションに参加すべきか決めかねることは少 なく感じました，会場は十分な広さが確保され，立ち見 の必要もなく集中して講演を聞くことができました。 ポ スターセッションでは, 軽食を摘みながらゆったりとし た雰囲気の中で議論することができました．

関西国際空港からオークランド空港へは直行便が就航 して㧍り，西日本からのアクセスは比較的容易です．空 港と市街地の間にはリムジンバスが発着しており, 難な く宿泊先へと到着することができました，会場のオーク ランド工科大学周辺は各国のテイストを味わえるレスト ランが多数見られ, 和食・中華・インド料理など, 好み の味から選ぶことができました.

\section{オーラルセッション}

2日目から 3 日目にかけて, 一般講演が行われました。 講演は質問時間込みで $15 \sim 25$ 分程度の時間でした。筆 者はMS\#3 : Novel synchrotron and neutron application セッ ションに扔ける David Keen教授のX線・中性子全散乱の 解析手法に注目しました。 氏は結晶・非晶質の局所構造 解析手法を行うソフトウェア “RMCprofile” の開発者で あり，その応用などについての紹介をされていました。 Reverse Monte Carlo (RMC) は全散乱やEXAFSによる局 所構造情報を手がかりとして三次元原子座標を導出する 方法であり，構造不規則系の原子配置や結晶に含まれる 崩れを描写する方法です. 本来, 結晶というと精密化さ れた結晶モデルで説明できるものと思われがちですが, 現実の材料では局所的な欠陥や崩れ，丕みが含まれてい ることがよくあります.RMCprofileでは粉末X線回折と 全散乱などの構造情報を組み合わせ, 結晶構造の精密化 を達成しつつも局所的な原子の乱れを含むような三次 元構造モデルを構築します. 電池材料や超イオン伝導体 などの特性を局所構造から理解するための方法として, 
今後 RMCのニーズは広がっていくと感じました.

初日の keynote lectureでは, 京都大学の北川宏教授が MOF (Metal Organic Frameworks) に関する講演をされま した.この講演において興味を惹いたのは, 材料の特性 と構造の次元を関係付ける点です。例えば, 2-leg ladder 型MOFに組み込まれた金属 $(\mathrm{Pt})$ 原子上の酸化数が規則 正しく配列されている場合, 三角 3-legもしくは四角 4-leg ladderにすると, 金属原子上の酸化数の規則性がどのよ うに変化するかに注目されていました，構造を特徽付け るための変数として次元数に注目することで, 特性 (あ るいは酸化数) との相関の見通しを良くすることができ る点は, ほかの材料の特性と構造の紐付けに応用できる と考えられます。

ポスターセッション

初日および2日目の夕刻に2時間程度の時間でポス ターセッションが行われました。ここでは多くの研究者 がMOFや生体分子構造と機能の解明について紹介して いました、筆者はこれらの研究に関する知識が浅く, 十 分に理解できたとは言えませんでしたが, 物理領域の講 演については深く議論することができました。例えば, 2018 年度日本結晶学会年会でポスター講演賞を受賞さ れた佐々木友彰氏 (筑波大学) が紹介していた, 粉末 X線回折より電子分布を実験的に決定する研究には, 大 変興味を惹かれました，密度汎関数理論に基づく電子状 態計算は, 近年の計算機とソフトウェアの発展により, いわゆる材料屋と呼ばれる研究者にとって1つの実験器 具とみなされるほど普及していますが, 一方でバンド ギャップに代表される計算值と測定值の食い違いは今
もなお残っています。氏の研究成果は，単に金属中の電 子分布描写という基礎物性の解明に留まらず, 電子状態 計算の改良・発展に資すると期待できると思いました。

筆者の講演は初日で, ナノ粒子の原子構造モデリング 手法についての紹介をいたしました，議論を通じ, 別手 法の解析結果と矛盾しないというご意見をいただくこと ができ, 筆者独自の視点の研究手法に対して自信をもつ ことができました。一方, 実施しているX線全散乱測定 および解析については，まだ十分に市民権が得られてい ない印象を受けたので, 今後研究を進め, 有用なプロー ブであることを示していかなければと感じました。

\section{おわりに}

AsCA2018にて多くの最新の研究成果に直接に接し, 他分野の出身である筆者は良い刺激を受けました，恥ず かしながら『結晶学』に関して, すでに多くの方々に研 究され尽くしている分野であるという先入観がありまし たが, 実際には cryo-EMや放射光施設などを利用した新 しい測定手法によって, まだまだ発展し続けていること を目の当たりにしたため, その先入観は打ち砕かれまし た. と同時に, 現状維持で満足していたらすぐに時代に 取り残されてしまう, という危機感も憶えました。一研 究者として常に次世代の研究を見据え, 新しい材料・解 析手法を探るためのアンテナを張り巡らせることが必要 と強く感じ, それに際して自身の研究者としての在り方 を見つめ直すいい機会となりました。

最後になりましたが, AsCA2018参加をご支援いただ きました日本結晶学会およびリガクファンドに哚く感謝 申し上げます。 